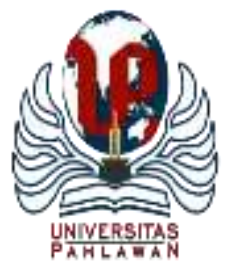

Edukatif : Jurnal Ilmu Pendidikan Volume 3 Nomor 6 Tahun 2021 Halm 4470 - 4482

EDUKATIF: JURNAL ILMU PENDIDIKAN

Research \& Learning in Education

https:/ledukatif.org/index.php/edukatif/index

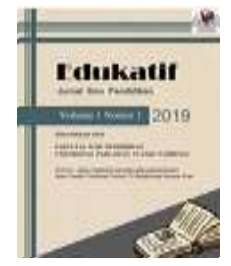

\title{
Pengembangan Modul IPA Berbasis Model Research Based Learning pada Keterampilan 4C Siswa Sekolah Dasar
}

\author{
Ressy Monica $^{1 凶}$, Zuhar Ricky $^{2}$, Estuhono $^{3}$ \\ Universitas Dharmas Indonesia, Indonesia ${ }^{1,2,3}$ \\ E-mail : ressymonica9@ gmail.com ${ }^{1}$, zuharricky@gmail.com ${ }^{2}, \underline{\text { estuhono023@gmail.com }}^{3}$
}

\begin{abstract}
Abstrak
Di SD 08 Sitiung Kabupaten Dharmasraya sudah memiliki modul, namun modul yang ada belum berbasis model research based learning pada keterampilan 4C siswa. Maka, tujuan penelitian ini adalah untuk menghasilkan modul IPA berbasis model research based learning pada keterampilan 4C siswa kelas IV. Jenis penelitian ini adalah penelitian pengembangan yaitu model pengembangan 4-D yang terdiri dari tahap pendefinisian (define), perancangan (design), pengembangan (development), dan penyebaran (desseminate). Penelitian ini dilakukan di kelas IV SD Negeri 08 Sitiung. Teknik pengumpulan data pada penelitian ini yaitu penyebaran angket dan penyebaran tes. Teknik analisis data yang digunakan dalam penelitian ini yaitu analisis data validitas, analisis praktikalitas dan analisis efektivitas. Hasil penilaian validasi modul yang dilakukan oleh tiga para ahli mempunyai skor validasi isi $86 \%$, validasi bahasa $79 \%$, dan validasi konstruk $89 \%$, dapatlah skor rata-rata validasi $85 \%$ dengan kategori sangat valid. Hasil penilaian praktikalitas modul yang dilakukan oleh guru kelas mempunyai skor $100 \%$ dengan kategori sangat praktis. Hasil penilaian efektivitas modul yang dilakukan siswa mempunyai persentase $74 \%$ dengan kategori efektif. Modul pembelajaran berbasis model RBL pada keterampilan 4C dapat digunakan sebagai alternatif sumber belajar untuk menunjang proses pembelajaran sehingga dapat membangkitkan $4 \mathrm{C}$ siswa.
\end{abstract}

Kata kunci: Modul, IPA, $R B L, 4 C$

\begin{abstract}
At SD 08 Sitiung, Dharmasraya Regency already has a module, but the existing module is not based on a research based learning model on students' $4 C$ skills. So, the purpose of this study is to produce a science module based on a research based learning model on the $4 C$ skills of fourth grade students. This type of research is development research, namely a 4-D development model consisting of the stages of defining, designing, developing, and distributing. This research was conducted in the fourth grade of SD Negeri 08 Sitiung. Data collection techniques in this study are the distribution of questionnaires and the distribution of tests. Data analysis techniques used in this research are validity data analysis, practicality analysis and effectiveness analysis. The results of the module validation assessment conducted by three experts had a content validation score of $86 \%$, language validation $79 \%$, and construct validation $89 \%$, with an average validation score of $85 \%$ with a very valid category. The results of the practicality assessment of the module conducted by the classroom teacher had a score of $100 \%$ in the very practical category. The results of the assessment of the effectiveness of the module by students have a percentage of $74 \%$ in the effective category. The RBL model-based learning module on $4 C$ skills can be used as an alternative learning resource to support the learning process so that it can generate $4 C$ students.
\end{abstract}

Keywords: Module, IPA, RBL, 4 C.

Copyright (c) 2021 Ressy Monica, Zuhar Ricky, Estuhono

$\triangle$ Corresponding author

Email : ressymonica9@gmail.com

DOI : https://doi.org/10.31004/edukatif.v3i6.1470

ISSN 2656-8063 (Media Cetak)

ISSN 2656-8071 (Media Online)

Edukatif : Jurnal Ilmu Pendidikan Vol 3 No 6 Tahun 2021 p-ISSN 2656-8063 e-ISSN 2656-8071 


\section{PENDAHULUAN}

Pendidikan adalah usaha sadar dan terencana untuk mewujudkan suasana belajar dan proses pembelajaran agar peserta didik secara aktif mengembangkan potensi dirinya untuk memiliki kekuatan spiritual keagamaan, pengendalian diri, kepribadian, kecerdasan, akhlak mulia, serta keterampilan yang diperlukan dirinya, masyarakat, bangsa dan negara. Salah satu penentu mutu pendidikan nasional adalah kualitas seorang guru. Guru adalah pendidik professional dengan tugas utama mendidik, mengajar, membimbing, mengarahkan, melatih, menilai, dan mengevaluasi peserta didik pada pendidikan anak usia dini jalur pendidikan formal, pendidikan dasar, dan pendidikan menengah Undang-Undang Republik Indonesia Nomor 14 Tahun 2005 Tentang Guru dan Dosen.

Undang-Undang Republik Indonesia Nomor 20 Tahun 2003 Tentang Sistem Pendidikan Nasional menyatakan bahwa kurikulum adalah seperangkat rencana dan pengaturan mengenai tujuan, isi, dan bahan pelajaran serta cara yang digunakan sebagai pedoman penyelenggaraan kegiatan pembelajaran untuk mencapai tujuan pendidikan tertentu. Dalam proses pembelajaran yang diinginkan dapat memperoleh alumnus yang mempunyai perilaku mulia maupun kreativitas, kemampuan yang signifikan, serta wawasan-wawasan yang terlibat. Maka, proses pembelajaran yang diinginkan dapat menghubungkan keaktifan peserta didik dengan optimal melalui pendekatan teacher centered learning ataupun student centered learning (Slameto, 2015).

Pada saat ini kurikulum yang ada di Indonesia menghadapi perbaikan, pertama kurikulum 2006 yang sering disebut dengan Kurikulum Tingkat Satuan Pendidikan (KTSP) saat ini disempurnakan menjadi kurikulum 2013. Kurikulum 2013 dipersiapkan dengan mengelaborasikan keselarasan antara tingkah laku psikis ataupun kemasyarakatan, keterampilan intelektual maupun kemampuan yang dilakukan dalam sistem pembelajaran. Pada kurikulum 2013 kompetensi inti maupun kompetensi dasar sudah ditentukan oleh pemerintah, langkah untuk menggapainya dan bahan ajar yang dipakai diberikan seutuhnya pada pendidik sebagai tenaga kerja yang berpengalaman untuk membuatnya (Usmeldi, 2016).

Pembelajaran dalam keterampilan abad 21, pendidik perlu memberi dorongan kepada peserta didik untuk ikut serta dalam proses pembelajaran secara teratur. Keterampilan abad 21 sering dikatakan dengan 4C yaitu keterampilan yang dapat dikuasai oleh peserta didik sebagai modal di abad 21 saat ini. Keterampilan abad 21 mampu mengembangkan serta memajukan kerjasama pada sebuah kelompok dalam menyelesaikan suatu masalah, menumbuhkan rasa toleransi atas perselisihan argumen teman, berusaha untuk berpikir kritis maupun kreatif dalam memecahkan suatu masalah tentang menghubungkan sesuatu (Septikasari \& Frasandy, 2018).

Berdasarkan hasil observasi yang dilakukan di SD Negeri 08 Koto Agung Kecamatan Sitiung Kabupaten Dharmasraya sudah memiliki modul, namun modul yang ada di sekolah tersebut belum berbasis model research based learning pada keterampilan 4C siswa. Selama ini keterampilan 4C siswa belum menjadi perhatian dan belum menerapkannya pada setiap mata pelajaran yang ada di SD 08 Sitiung Kabupaten Dharmasraya. Maka, keterampilan 4C siswa belum tercapai.

Pendidikan formal, pembelajaran sudah dituntut untuk melaksanakan kemampuan 4C (Creativity and Innovation, Collaboration, Communication, Critical Thinking and Problem Solving) ini bisa terbentuk secara cepat, bukan hanya tuntutan pada kemampuan pendidik dalam mengganti teknik mengajar, namun juga tanggung jawab pendidik untuk melatih peserta didik dalam melaksanakan 4C di kehidupan sehari-hari (Sugiyarti et al., 2018). Keterampilan 4C dapat digabungkan dalam beraneka ragam mata pelajaran, seperti mata pelajaran IPA (Ilmu Pengetahuan Alam). Salah satu mata pelajaran yang berperan penting dan dianggap cukup sulit yaitu pelajaran Ilmu Pengetahuan Alam (IPA) (Jannah et al. 2021) dalam (Widiya Mareta, 2021). IPA merupakan mata pelajaran sains yang menjelaskan berbagai gejala fisik fenomena yang terjadi di alam, baik secara teoritis maupun matematis (Estuhono, 2020). Pada hakikatnya, IPA merupakan ilmu pengetahuan 
untuk mengetahui apa saja yang berkaitan pada isi jagat raya (Saputro, 2018), sehingga diharapkan jika keterampilan 4C bisa digabungkan dengan pembelajaran IPA melalui beraneka macam model pembelajaran yang sesuai, sehingga peristiwa ini dapat memecahkan beragam masalah yang ditemui peserta didik di kehidupan sehari - hari. Salah satu model pembelajaran yang dapat mendorong peserta didik agar dapat berpikir secara kritis, berkomunikasi dengan baik, saling bekerja sama (collaboration) dan mampu mendapatkan sesuatu yang baru (creativity) yakni dengan menggunakan model research based learning.

Model research based learning adalah model pembelajaran yang menuju dalam kegiatan analisis, sintesis maupun evaluasi dan mengembangkan pengetahuan peserta didik maupun pendidik dalam hal asimilasi serta aplikasi pengetahuan. Model research based learning mampu meningkatkan kemampuan peserta didik supaya dapat berpikir kritis maupun kreatif dan mampu memecahkan masalah dengan benar serta terstruktur (Hidayah, 2018). Model research based learning yaitu salah satu metode student centered learning yang menyatukan riset di dalam tahap pembelajaran. Hal ini dikarenakan pentingnya implementasi model research based learning sebagai upaya untuk membantu peserta didik membangun kemampuan intelektual dan kemampuan praktis (Estuhono, 2019).Oleh karena itu, dengan hal tersebut untuk mempersiapkan peserta didik yang mempunyai keterampilan 4C (Creativity and Innovation, Collaboration, Communication, Critical Thinking and Problem Solving,) dibutuhkan sebuah bahan ajar yang cocok, yakni dengan memakai modul.

Salah satu upaya untuk menekankan keterampilan 4C adalah menggunakan bahan ajar seperti modul. Modul merupakan bahan ajar yang bersifat mandiri, sehingga peserta didik dituntut untuk secara mandiri tanpa adanya bimbingan guru secara langsung. Keberadaan modul sangat diperlukan untuk menunjang keberhasilan tujuan pembelajaran yang diharapkan karena mampu memberikan informasi dan membantu kegiatan belajar peserta didik agar lebih terarah. Berdasarkan permasalahan yang ditemukan oleh peneliti, maka rumusan masalah dalam penelitian ini adalah bagaimana mengembangkan modul IPA berbasis model research based learning pada keterampilan 4C siswa pokok bahasan tema daerah tempat tinggalku tentang gaya dan gerak yang valid, praktis dan efektif?.

\section{METODE PENELITIAN}

Penelitian yang digunakan peneliti adalah jenis penelitian pengembangan (Research and Development), karena peneliti akan mengembangan produk bahan ajar berupa modul IPA materi gaya dan gerak berbasis research based learning pada keterampilan 4C siswa.

Menurut Borg and Gall (1998) dalam Ainin (2013) berpendapat bahwa metode penelitian pengembangan merupakan suatu metode riset yang tujuannya untuk mengembangkan dan memvalidasi produk tertentu. Untuk menghasilkan produk tertentu digunakan penelitian bersifat analisis kebutuhan dan untuk mengkaji keefektifan produk agar bisa dipakai di sekolah. Data yang diambil oleh peneliti yaitu data kualitatif dan kuantitatif. Data kualitatif dan kuantitatif adalah data yang diambil dari hasil validasi yang dilakukan oleh validator, data praktikalitas diambil melalui angket respon guru serta data efektivitas yang diambil melalui penyebaran angket respon siswa dan tes soal terhadap modul IPA berbasis model research based learning pada keterampilan 4C siswa.

Dalam pengembangan modul ini menggunakan model 4-D (Define, Design, Development and Desseminate).

\section{Pendefinisian (define)}

Tahap ini melakukan kegiatan analisis kebutuhan, analisis kurikulum dan analisis karakteristik siswa serta model penelitian dan pengembangan yang cocok digunakan untuk mengembangkan produk. Dilihat dari kondisi SDN 08 Sitiung bahwa di sekolah tersebut sudah memiliki modul, tetapi modul yang 
ada belum berbasis model research based learning pada keterampilan 4C dan masih menggunakan buku siswa dan buku guru saat pembelajaran, sehingga bahan ajar belum menekankan keterampilan 4C siswa, maka keterampilan 4C siswa belum menjadi perhatian dan belum menerapkannya pada setiap mata pelajaran yang ada, sehingga keterampilan $4 \mathrm{C}$ siswa belum tercapai. Oleh karena itu, dari permasalahan tersebut di perlukan adanya bahan ajar berbentuk modul berbasis model research based learning pada keterampilan 4C siswa.

2. Perancangan (design)

Tahap ini melakukan perancangan (design) sebuah produk berupa modul, penyusunan instrumen validitas, instrumen praktikalitas dan instrumen efektivitas.

a. Instrumen Validitas

Menurut Azwar (2017) dalam Sulistiawan Agus,dkk (2020) validitas yaitu ketentuan serta kesiapan alat ukur dalam memenuhi peran ukurnya. Arikunto (2008:97) dalam Rahayu \& Festiyed, (2018) mengatakan bahwa validitas merupakan suatu ukuran yang menentukan tingkat kepandaian atau keabsahan. Berarti validitas merupakan penilaian akan suatu produksi yang dibuat apakah telah seimbang untuk dipakai. Azwar (1987: 173) dalam Matondang Zulkifli (2009) menyatakan bahwa validitas berasal dari kata validity yang memiliki pemahaman sejauh mana ketntuan dan kesiapan suatu instrumen pengukur (tes) dalam melaksanakan peran ukurnya.

Berdasarkan pengertian para ahli di atas, dapat disimpulkan bahwa validitas adalah ukuran ketepatan dari suatu instrumen yang diukur. Validitas bahan ajar cetak dan non cetak adalah ukuran ketepatan suatu bahan ajar sesuai dengan kompetensi, dan tujuan pembelajaran.

Analisis data validitas dilakukan dengan menggunakan skala likert 1-4 dengan skor 1 jika Tidak Setuju (TS), skor 2 jika Kurang Setuju (KS), skor 3 jika Setuju (S), skor 4 jika Sangat Setuju (SS). Dari skor yang diperoleh di hitung nilai validitasnya dengan menggunakan persamaan berikut:

$$
V=\frac{f}{n} \times 100 \%
$$

Dimana $\mathrm{V}$ merupakan nilai validitas, $\mathrm{f}$ merupakan skor yang diperoleh, $\mathrm{n}$ merupakan skor maksimum. Kategori validitas bahan ajar berdasarkan nilai akhir yang diperoleh dalam skala (0-100) bisa dilihat pada Tabel berikut:

Tabel 1. Kategori Validitas

\begin{tabular}{cc}
\hline Interval & Kategori \\
\hline $0 \leq \mathrm{V} \leq 20$ & Sangat tidak valid \\
\hline $21 \leq \mathrm{V} \leq 40$ & Tidak valid \\
\hline $41 \leq \mathrm{V} \leq 60$ & Kurang valid \\
\hline $61 \leq \mathrm{V} \leq 80$ & Valid \\
\hline $81 \leq \mathrm{V} \leq 100$ & Sangat valid \\
\hline (Dimodifikasi dari Riduwan, 2013) dalam (Aziz \& Prasetya, 2018)
\end{tabular}

b. Instrumen Praktikalitas

Menurut Kamus Besar Bahasa Indonesia, praktikalitas berarti bahwa bersifat praktis, artinya mudah dan senang memakainya. Kepraktisan yang dimaksud disini adalah kepraktisan dalam bidang pendidikan (bahan ajar, instrumen, maupun produk yang lainnya). Praktikalitas berkaitan dengan kemudahan dan kemajuan yang didapatkan siswa dengan menggunakan bahan ajar, instrumen, maupun produk yang lainnya (Marlini Cut, 2019). Praktikalitas merupakan tingkat keterpakaian atau kemudahan bahan ajar untuk digunakan (Agustyaningrum \& Gusmania, 2017). Praktikalitas adalah membuat sesuatu menjadi lebih mudah, tidak menjadi penghalang dalam melakukan sesuatu dan memberikan kemudahan saat dipakai (Fikriani, 2016). 
Berdasarkan beberapa pendapat di atas, dapat disimpulkan bahwa praktikalitas adalah mudah dan senang dalam pemakainnya. Kemudahan tersebut harus sesuai dengan perkembangan peserta didik, bahasa yang digunakan mudah dipahami serta meningkatkan motivasi.

Analisis praktikalitas diperoleh dari hasil penilaian yang akan dilakukan oleh guru dan peserta didik kelas IV SDN 08 Sitiung. Analisis data praktikalitas dilakukan dengan menggunakan skala likert 1-4 dengan skor 1 jika Tidak Setuju (TS), skor 2 jika Kurang Setuju (KS), skor 3 jika Setuju (S), skor 4 jika Sangat Setuju (SS). Dari skor yang diperoleh di hitung nilai validitasnya dengan menggunakan persamaan berikut:

$$
P=\frac{f}{n} \times 100 \%
$$

Dimana $\mathrm{P}$ merupakan nilai praktikalitas, $\mathrm{f}$ merupakan skor yang diperoleh, $\mathrm{n}$ merupakan skor maksimum. Kategori validitas bahan ajar berdasarkan nilai akhir yang diperoleh dalam skala (0-100) bisa dilihat pada Tabel berikut:

Tabel 2. Kategori Praktikalitas

\begin{tabular}{cc}
\hline Interval & Kategori \\
\hline $0 \leq \mathrm{P} \leq 20$ & Sangat tidak valid \\
\hline $21 \leq \mathrm{P} \leq 40$ & Tidak valid \\
\hline $41 \leq \mathrm{P} \leq 60$ & Kurang valid \\
\hline $61 \leq \mathrm{P} \leq 80$ & Valid \\
\hline $81 \leq \mathrm{P} \leq 100$ & Sangat valid \\
\hline
\end{tabular}

(Dimodifikasi dari Riduwan, 2013) dalam (Aziz \& Prasetya, 2018)

\section{c. Instrumen Efektivitas}

Efektivitas berasal dari kata dasar efektif. Menurut Kamus Besar Bahasa Indonesia, kata efektif mempunyai arti efek, pengaruh, akibat atau dapat membawa hasil. Jadi, efektivitas adalah keaktifan, daya guna adanya keteraturan dalam suatu kegiatan orang yang melakukan tugas dengan sasaran yang dituju (Mingkid Gary.J, 2017). Efektivitas merupakan ukuran berhasil tidaknya dalam menggapai tujuannya (Chandra et al., 2020). Kata efektif berasal dari bahasa inggris yaitu effective yang berarti berhasil atau sesuatu yang dilaksanakan berhasil dengan baik. Hidayat (1986) dalam (Anggraini, 2018) menjelaskan bahwa efektivitas merupakan suatu ukuran yang menyatakan seberapa jauh target (kuantitas, kualitas dan waktu) telah tercapai.

Berdasarkan beberapa pendapat di atas, dapat disimpulkan bahwa efektivitas adalah suatu kondisi yang menunjukkan tingkat keberhasilan atau pencapaian suatu tujuan yang diukur dengan kualitas, kuantitas dan waktu sesuai dengan apa yang telah direncanakan sebelumnya.

Keefektifan modul dapat diketahui dengan menganalisis data tes hasil belajar siswa. Penskoran untuk masing - masing tes belajar di analisis dalam skala 0-100, diharapkan siswa bisa mencapai Kriteria Ketuntasan Minimal (KKM) yang sudah ditetapkan yaitu 75. Persentase menggunakan persamaan:

$$
E=\frac{f}{n} \times 100 \%
$$

Dimana E merupakan nilai efektivitas, $\mathrm{f}$ merupakan skor yang diperoleh, $\mathrm{n}$ merupakan skor maksimum. Kategori validitas bahan ajar berdasarkan nilai akhir yang diperoleh dalam skala (0-100) bisa dilihat pada Tabel berikut: 
Tabel 3. Kategori Efektivitas

\begin{tabular}{|c|c|}
\hline Interval & Kategori \\
\hline $0 \leq \mathrm{P} \leq 20$ & Sangat tidak valid \\
\hline $21 \leq \mathrm{P} \leq 40$ & Tidak valid \\
\hline $41 \leq \mathrm{P} \leq 60$ & Kurang valid \\
\hline $61 \leq \mathrm{P} \leq 80$ & Valid \\
\hline $81 \leq \mathrm{P} \leq 100$ & Sangat valid \\
\hline
\end{tabular}

(Dimodifikasi dari Riduwan, 2013) dalam (Aziz \& Prasetya, 2018)

\section{Pengembangan (development)}

Tahap ini bertujuan untuk menerjemahkan spesifikasi perancangan perangkat pembelajaran IPA materi gaya dan gerak berbasis model RBL pada keterampilan 4C kedalam bentuk fisik atau wujud nyata produk. Sehingga dalam kegiatan ini menghasilkan bentuk produk pengembangan yaitu bahan ajar IPA materi gaya dan gerak berbasis model RBL pada keterampilan 4C yang masih perlu di uji kevalidannya. Kemudian bentuk bahan ajar di evaluasi oleh validator untuk mengetahui tingkat validnya, apabila belum memenuhi kriteria valid maka dilakukan perbaikan.

\section{Penyebaran (desseminate)}

Tahap ini dibagi menjadi tiga kegiatan, yaitu: validation testing, packaging, diffusion, and adoption. Pada tahap validation testing (pengujian validasi), produk yang sudah direvisi pada tahap pengembangan kemudian diimplementasikan dilakukan pengukuran ketercapaian tujuan. Pengukuran ini dilakukan untuk mengetahui efektivitas produk yang dikembangkan. Setelah produk diimplementasikan, peneliti perlu melihat hasil pencapaian tujuan. Kegiatan terakhir dari tahap pengembangan adalah melakukan packaging (pengemasan), diffusion and adoption. Pengemasan model pembelajaran dapat dilakukan dengan mencetak buku panduan penerapan model pembelajaran. Setelah buku dicetak, buku tersebut disebarluaskan supaya dapat diserap (difusi) atau dipahami orang lain dan digunakan (diadopsi) pada kelas mereka.

Teknik analisis data yang diterapkan dalam penelitian pengembangan ini adalah dengan cara mengumpulkan data melalui instrumen - instrumen pengumpulan data, kemudian di analisis dengan mengacu pada prosedur penelitian dan pengembangan. Data yang di analisis nantinya adalah kuantitatif digunakan untuk mendeskripsikan penelitian kualitas produk berdasarkan kevalidan, kepraktisan dan keefektifan. Analisis validitas digunakan untuk mengetahui kevalidan dari bahan ajar yang digunakan berdasarkan dengan hasil penilaian validator, analisis kepraktisan digunakan untuk mengetahui seberapa tingkat kepraktisan dari bahan ajar yang digunakan, dan analisis keefektifan digunakan untuk mengetahui tingkat keefektifan soal tes yang diberikan kepada siswa.

\section{HASIL DAN PEMBAHASAN PENELITIAN}

\section{Data hasil pendefinisian atau define}

1. Analisis kebutuhan, sesuai dengan kebutuhan bahwasanya saat pembelajaran menggunakan modul berbasis model research based learning pada keterampilan 4C siswa. Sehingga keterampilan 4C siswa sudah tercapai.

2. Analisis kurikulum. Dalam Tema 8 Daerah Tempat Tinggalku pada pembelajaran IPA di SD Negeri 08 Sitiung sebagai tempat uji coba bahan ajar menggunakan K13. Standar Kompetensi: "Menggali informasi tentang materi gaya dan gerak, menjelaskan kembali materi hubungan antara gaya dan gerak pada peristiwa lingkungan disekitar. Keterlaksanaan pembelajaran yang baik diharapkan mampu 
4476 Pengembangan Modul IPA Berbasis Model Research Based Learning pada Keterampilan 4C Siswa Sekolah Dasar-Ressy Monica, Zuhar Ricky, Estuhono

DOI: https://doi.org/10.31004/edukatif.v3i6.1470

meningkatkan hasil belajar siswa pada ranah pengetahuan, pemahaman dan keterampilan terhadap pembelajaran IPA".

3. Analisis karakteristik siswa, sesuai dengan teori kognitif oleh Jean Piaget bahwa siswa kelas IV SD berada pada fase operasional konkret (usia 7 - 11), pada tahap ini siswa mampu mengurutkan objek dan situasi - situasi yang dihadapi. Siswa juga mampu untuk mengingat dan berpikir secara logis.

\section{Tahap Perancangan atau design}

Hasil tahap perancangan yang telah dilakukan oleh peneliti adalah sebagai berikut:

Hasil penyusunan instrumen penelitian

a. Lembar Instrumen Validitas. Pada lembar validitas ini terdapat petunjuk pengisian dan tiga aspek yang dinilai, yaitu aspek kelayakan isi, aspek konstruk dan aspek bahasa yang akan di isi oleh validator atau para ahli.

b. Lembar Instrumen Praktikalitas. Pada hasil rancangan lembar praktikalitas terdapat petunjuk pengisian dan aspek - aspek yang dinilai oleh guru dan siswa.

c. Lembar Instrumen Efektivitas. Pada hasil rancangan lembar efektivitas terdapat petunjuk pengisian dan aspek dinilai oleh siswa.

Hasil Rancangan Kerangka Modul

Penyajian modul ini disusun secara urut yang terdiri dari halaman sampul atau cover, kata pengantar. Adapun komponen - komponen tersebut akan dibahas lebih rinci dapat dilihat pada gambar sebagai berikut:

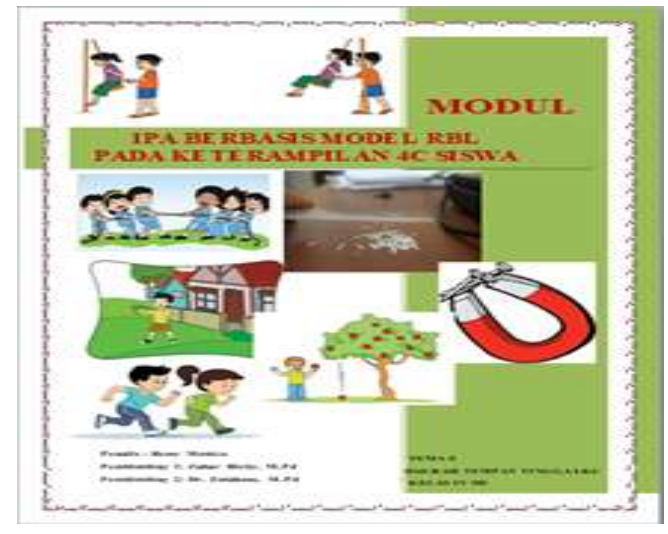

Gambar 1. Halaman Sampul (Cover)

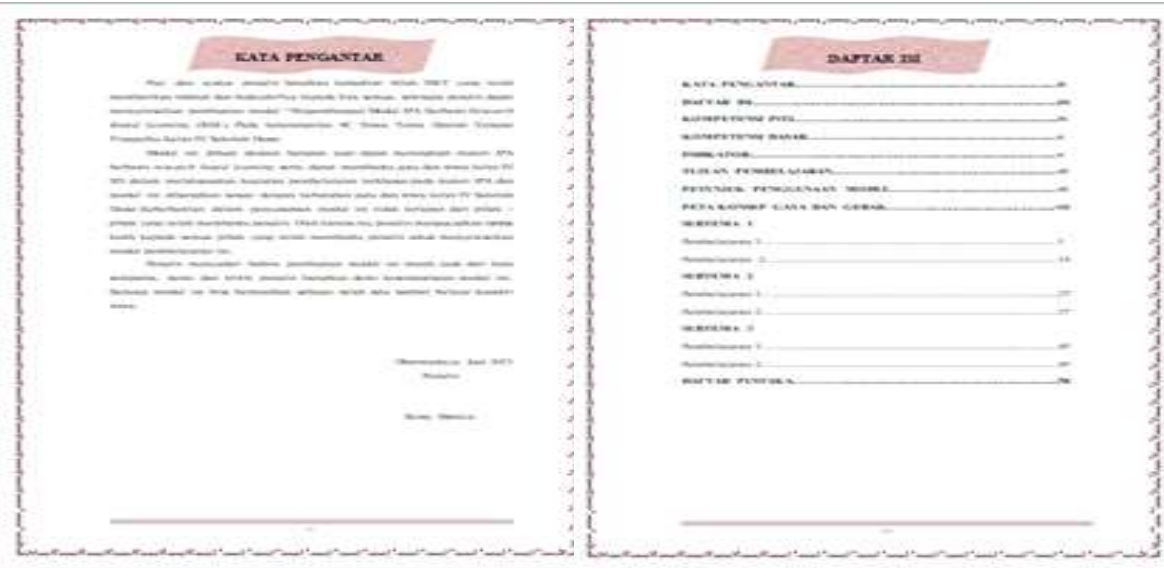

Gambar 2. Kata Pengantar dan Daftar Isi 
4477 Pengembangan Modul IPA Berbasis Model Research Based Learning pada Keterampilan 4C Siswa Sekolah Dasar-Ressy Monica, Zuhar Ricky, Estuhono

DOI: https://doi.org/10.31004/edukatif.v3i6.1470

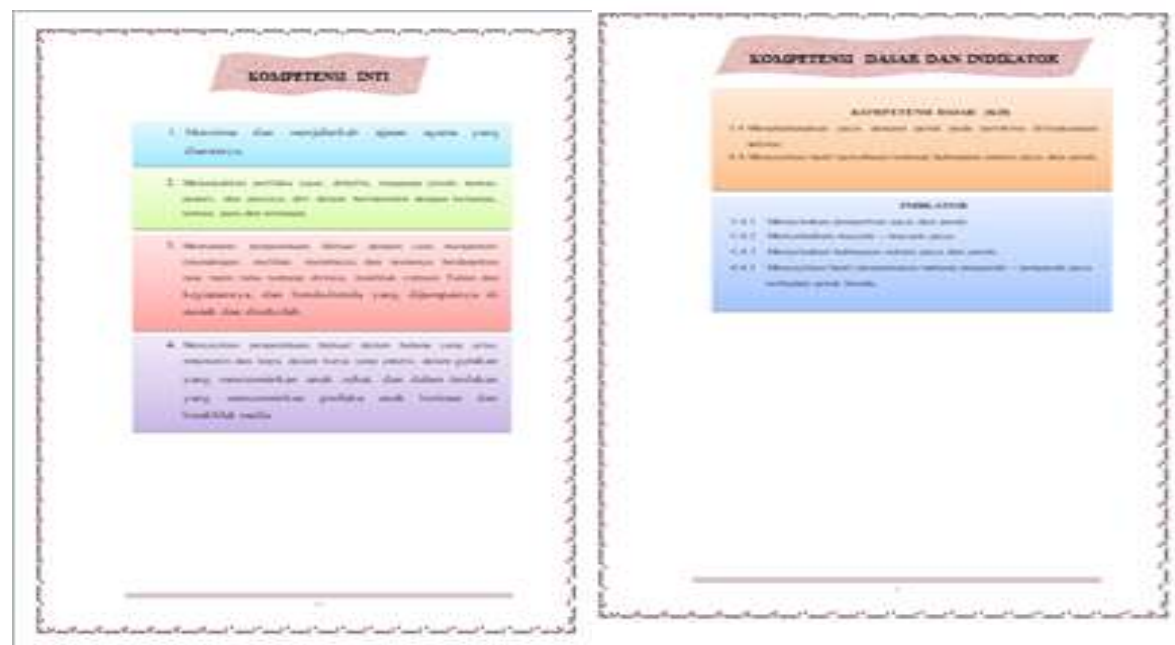

Gambar 3. Satuan Pendidikan

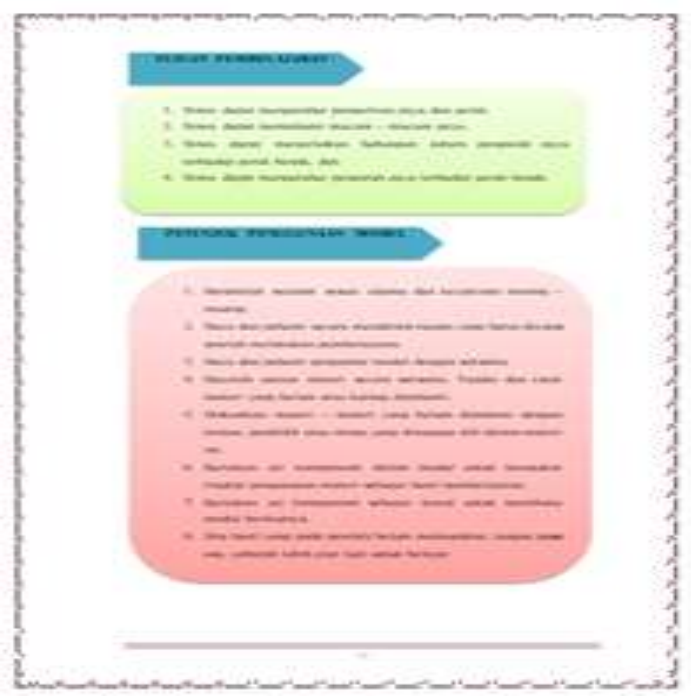

Gambar 4.Tujuan Pembelajaran dan Petunjuk Penggunaan Modul
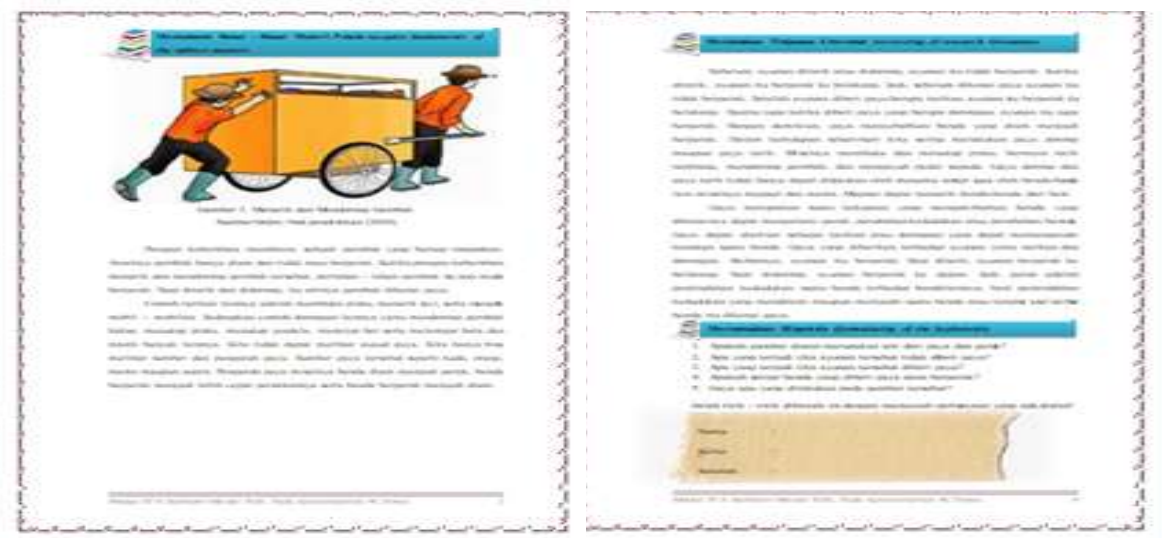

Gambar 5. Pengantar Materi

Edukatif : Jurnal Ilmu Pendidikan Vol 3 No 6 Tahun 2021 p-ISSN 2656-8063 e-ISSN 2656-8071 
4478 Pengembangan Modul IPA Berbasis Model Research Based Learning pada Keterampilan 4C Siswa Sekolah Dasar-Ressy Monica, Zuhar Ricky, Estuhono

DOI: https://doi.org/10.31004/edukatif.v3i6.1470
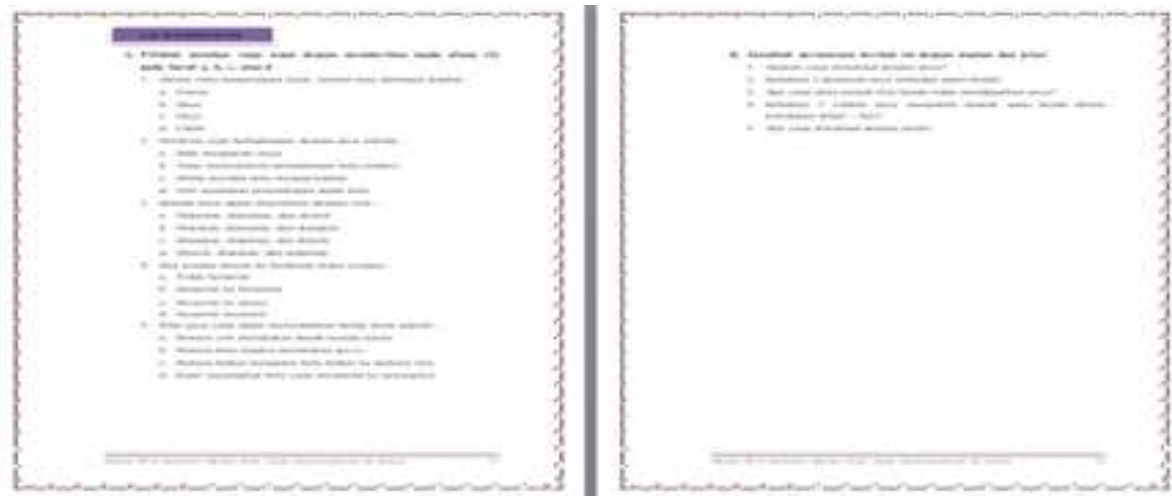

Gambar 6. Uji Kompetensi

\section{Tahap Pengembangan atau development}

Data Validitas

Data diperoleh dari hasil validitas modul yang dilakukan oleh tiga validator dapat dilihat pada tabel 4 sebagai berikut:

Tabel 4. Data Hasil Validasi

\begin{tabular}{ccc}
\hline Validator & Hasil & Kategori \\
& $\mathrm{V}=\frac{f}{n} \times 100$ & Sangat Valid \\
\hline Moh Rosyid Mahmudi, M.Si & $\mathrm{V}=\frac{31}{36} \times 100 \%$ & \\
\hline Dr. Raimon Efendi, M.Kom & $\mathrm{V}=\frac{25}{28} \times 100 \%$ & Sangat Valid \\
\hline Aprimadedi, S.S, M.Pd & $\mathrm{V}=89 \%$ & Sangat Valid \\
\hline Rata-Rata & $\mathrm{V}=79 \% \times 100 \%$ & Sangat Valid \\
\hline
\end{tabular}

Dari tabel 4, dapat dilihat bahwa hasil validitas yang dilakukan oleh ketiga validator memberikan hasil rata - rata nilai 85\% (Sangat Valid) sehingga modul bisa diterapkan di Sekolah Dasar.

Data Praktikalitas

Data praktikalitas pada uji coba produk yang telah dibuat oleh peneliti, dapat dilihat pada tabel 5 sebagai berikut:

Tabel 5. Data Praktikalitas

\begin{tabular}{ccc}
\hline Praktisi & Nilai \% & Kategori \\
\hline Sri Harmini, S.Pd (Guru Kelas IV) & $100 \%$ & Sangat Praktis \\
\hline Syafiardi, S.Pd (Guru Kelas VI) & $100 \%$ & Sangat Praktis \\
\hline
\end{tabular}

Berdasarkan analisis data penilaian kepraktisan oleh praktisi memperoleh hasil $100 \%$ dengan kategori sangat praktis. 
4479 Pengembangan Modul IPA Berbasis Model Research Based Learning pada Keterampilan 4C Siswa Sekolah Dasar-Ressy Monica, Zuhar Ricky, Estuhono

DOI: https://doi.org/10.31004/edukatif.v3i6.1470

\section{Data Efektivitas}

Data efektivitas diperoleh dari hasil belajar peserta didik tes objektif setelah melakukan pembelajaran dengan menggunakan modul IPA berbasis model research based learning dapat dilihat pada tabel 6 sebagai berikut:

Tabel 6. Data Hasil Efektivitas

\begin{tabular}{ccc}
\hline Tuntas/Tidak Tuntas & Jumlah & Persentase (\%) \\
\hline Tuntas & 14 & $74 \%$ \\
\hline Tidak Tuntas & 5 & $26 \%$ \\
\hline
\end{tabular}

\section{Tahap Penyebaran atau desseminate}

Tahap ini dibagi menjadi tiga kegiatan, yaitu: validation testing, packaging, diffusion, and adoption. Pada tahap validation testing (pengujian validasi), produk yang sudah direvisi pada tahap pengembangan kemudian diimplementasikan dilakukan pengukuran ketercapaian tujuan. Pengukuran ini dilakukan untuk mengetahui efektivitas produk yang dikembangkan. Setelah produk diimplementasikan, peneliti perlu melihat hasil pencapaian tujuan. Kegiatan terakhir dari tahap pengembangan adalah melakukan packaging (pengemasan), diffusion and adoption . Pengemasan model pembelajaran dapat dilakukan dengan mencetak buku panduan penerapan model pembelajaran. Setelah buku dicetak, buku tersebut disebarluaskan supaya dapat diserap (difusi) atau dipahami orang lain dan digunakan (diadopsi) pada kelas mereka.

\section{Pembahasan}

Berdasarkan data yang diperoleh dari pengembangan modul IPA berbasis RBL kelas IV SD. Maka diperoleh dengan kategori sangat valid, praktis dan efektif.

\section{Validitas Modul IPA Berbasis RBL}

Pengembangan modul dilakukan dalam rangka menunjang proses pembelajaran dan penilaian. Modul yang digunakan harus valid sehingga layak digunakan dalam proses pembelajaran. Dalam penelitian ini, validasi yang dilakukan menekankan pada validasi isi, konstruk dan bahasa. Modul yang dikembangkan telah sesuai dengan kriteria yang seharusnya dan susunan dari mdoul yang dibuat sudah memenuhi syaratsyarat penyusunan modul.

Berdasarkan hasil validasi modul IPA materi gaya dan gerak berbasis model RBL pada keterampilan 4C siswa memiliki persentase penilaian validasi isi $86 \%$, validasi konstruk $89 \%$, validasi bahasa $79 \%$. Modul yang telah dinilai sangat valid selanjutnya dapat diuji cobakan. Persentase penilaian terhadap modul yang dikembangkan tidak ada yang mencapai nilai $100 \%$. Hal ini mengindikasikan bahwa pengembangan modul perlu dilakukan secara berkesinambungan dalam rangka penyempurnaan untuk memperoleh modul yang layak digunakan dalam proses pembelajaran.

Modul dinyatakan sangat valid oleh validator karena modul sudah berbasis model RBL dalam materi gaya dan gerak pada keterampilan 4C siswa. Sugiyono (2007:173), menyatakan bahwa "suatu instrumen dikatakan valid bila instrumen tersebut dapat digunakan untuk mengukur apa yang seharusnya diukur". Uji validitas yang dilakukan meliputi: validitas isi, validitas konstruk, dan validitas bahasa.

Berdasarkan isinya modul dinyatakan sangat valid oleh validator karena modul yang dikembangkan telah sesuai dengan materi yang seharusnya disajikan. Sedangkan Riduan (2009:87), mengatakan bahwa "untuk menguji validitas konstruksi dapat digunakan pendapat para ahli". Berdasarkan konstruksinya perangkat yang dihasilkan sangat valid karena penyusunannya sudah mengacu pada Permen 41 Tahun 2007 tentang standar proses. Sementara dari segi bahasanya perangkat yang dihasilkan juga berkategori sangat valid karena sudah menggunakan tata bahasa Indonesia yang baku. 


\section{Praktikalitas Modul IPA Berbasis RBL}

Praktikalitas suatu modul pembelajaran dilihat dari hasil uji coba modul pembelajaran dalam proses pembelajaran. Modul pembelajaran dikatakan praktis jika terdapat konsistensi antara tipologi harapan dan penilaian, serta harapan dan operasional". Praktikalitas modul pembelajaran dianalisis dari substansi yang meliputi hasil analisis respon guru.

Hasil analisis dari angket respon yang diisi oleh guru menunjukkan bahwa tanggapan guru terhadap modul $100 \%$ yang berkategori sangat praktis. Modul pembelajaran yang dikembangkan telah membantu guru dalam mewujudkan tercapainya tujuan pembelajaran dan indikator pencapaian kompetensi yang telah disusun. Guru juga terbantu dalam mengembangkan $4 \mathrm{C}$ siswa. Hal ini menunjukkan bahwa modul dapat digunakan dengan baik.

\section{Efektivitas Modul IPA Berbasis RBL}

Kata efektif berasal dari bahasa inggris yaitu effective yang berarti berhasil atau sesuatu yang dilaksanakan berhasil dengan baik. Hidayat (1986) dalam (Anggraini, 2018) menjelaskan bahwa efektivitas merupakan suatu ukuran yang menyatakan seberapa jauh target (kuantitas, kualitas dan waktu) telah tercapai. Berdasarkan beberapa pendapat di atas, dapat disimpulkan bahwa efektivitas adalah suatu kondisi yang menunjukkan tingkat keberhasilan atau pencapaian suatu tujuan yang diukur dengan kualitas, kuantitas dan waktu sesuai dengan apa yang telah direncanakan sebelumnya. Keefektifan modul dapat diketahui dengan menganalisis data tes hasil belajar siswa. Penskoran untuk masing - masing tes belajar di analisis dalam skala 0-100, diharapkan siswa bisa mencapai Kriteria Ketuntasan Minimal (KKM) yang sudah ditetapkan yaitu 75 .

Efektivitas modul dilihat berdasarkan pencapaian dari hasil belajar siswa. Hasil belajar diambil selama proses pembelajaran berlangsung menggunakan modul pembelajaran materi gaya dan gerak berbasis model RBL pada keterampilan 4C siswa. Analisis hasil belajar siswa menunjukkan pencapaian yang baik. Ratarata nilai siswa yang tuntas adalah $74 \%$ sedangkan yang tidak tuntas mendapatkan $26 \%$. Pengembangan modul IPA materi gaya dan gerak berbasis model RBL pada keterampilan 4C dapat dikatakan efektif.

\section{KESIMPULAN}

Berdasarkan kesimpulan yang didapatkan modul pembelajaran berbasis model RBL pada keterampilan 4C bisa memberikan masukan bagi penyelenggara pendidikan. Modul pembelajaran berbasis model RBL pada keterampilan 4C dapat dijadikan bahan pertimbangan untuk digunakan mencapai indikator dan tujuan pembelajaran. Modul pembelajaran berbasis model RBL pada keterampilan 4C dapat digunakan sebagai alternatif sumber belajar untuk menunjang proses pembelajaran dalam mencapai indikator dan tujuan pembelajaran. Modul pembelajaran berbasis model RBL dapat membangkitkan 4C siswa (Creativity and innovation, Collaboration, Communication, Critical thinking and problem solving).

Pengembangan modul pembelajaran berbasis model RBL pada keterampilan 4C juga dapat dilakukan oleh guru-guru disekolah, mahasiswa yang mengambil kuliah dibidang pendidikan, lembaga pendidikan, dan praktisi pendidikan, tetapi prosesnya harus mengacu kepada tatacara penelitian pengembangan agar diperoleh modul yang baik dan layak dipakai dalam proses pembelajaran. Modul pembelajaran berbasis model RBL pada keterampilan 4C dapat digunakan sebagai salah satu modul yang mendukung pelaksanaan proses pembelajaran. 
4481 Pengembangan Modul IPA Berbasis Model Research Based Learning pada Keterampilan 4C Siswa Sekolah Dasar-Ressy Monica, Zuhar Ricky, Estuhono

DOI: https://doi.org/10.31004/edukatif.v3i6.1470

\section{DAFTAR PUSTAKA}

Agustyaningrum, N., \& Gusmania, Y. (2017). Praktikalitas Dan Keefektifan Modul Geometri Analitik Ruang Berbasis Konstruktivisme. Jurnal Dimensi, 6(3), 412-420. Https://Doi.Org/10.33373/Dms.V6i3.1075

Anggraini, W. W. (2018). Efektivitas Program Pendidikan Luar Sekolah Dalam Kejar Paket C Di Pusat Kegiatan Belajar Masyarakat "Variant Centre" Kelurahan Petemon Kecamatan Sawahan Kota Surabaya. Aplikasi Administrasi: Media Analisa Masalah Administrasi, $20(1), \quad 39$. Https://Doi.Org/10.30649/Aamama.V20i1.91

Aziz, R., \& Prasetya, S. P. (2018). Pengembangan Media Pembelajaran Maket 3D Geo Grafi Pada Materi Lipatan Dan Patahan Pengembangan Media Pembelajaran Maket 3D Pada Materi Lipatan Dan Patahan. Swara Bhumi, 5(9).

Chandra, C. A., Sabijono, H., \& Runtu, T. (2020). Efektivitas Dan Kontribusi Penerimaan Pajak Bumi Dan Bangunan Perdesaan Dan Perkotaan (Pbb-P2) Terhadap Penerimaan Pendapatan Asli Daerah (Pad) Di Kota Gorontalo Tahun 2016-2018. Going Concern: Jurnal Riset Akuntansi, 15(3), 290. Https://Doi.Org/10.32400/Gc.15.3.28541.2020

Estuhono. (2020). EFEKTIFITAS PENGEMBANGAN PERANGKAT PEMBELAJARAN IPA BERBASIS MODEL PROBLEM BASED INSTRUCTION TERINTEGRASI PENDIDIKAN KARAKTER UNTUK SISWA SEKOLAH DASAR. 5(2), 202-209.

Estuhono, Festiyed, \& Bentri, A. (2019). Preliminary Research Of Developing A Research-Based Learning Model Integrated By Scientific Approach On Physics Learning In Senior High School. Journal Of Physics: Conference Series, 1185(1). Https://Doi.Org/10.1088/1742-6596/1185/1/012041

Fikriani, T. (2016). Pengembangan Perangkat Pembelajaran Matematika Dengan Model Guided Inquiry Untuk Meningkatkan Kemampuan Pemecahan Masalah Matematika Peserta Didik Kelas VIII SMP/Mts. Journal Of Chemical Information And Modeling, 53(9), 1689-1699.

Hidayah, R. (2018). Jurnal Bidang Pendidikan Dasar (JBPD), Vol.2 No.2 Juni 2018 Http: Ejournal.Unikama.Ac.Id/Index.Php/JBPD. Jurnal Bidang Pendidikan Dasar, 2(2), 53-61.

Marlini Cut. (2019). PRAKTIKALITAS PENGGUNAAN MEDIA PEMBELAJARAN MEMBACA PERMULAAN BERBASIS MACROMEDIA FLASH. Jurnal Tunas Bangsa, 6(2), 277-289.

Matondang, Z., \& Pendahuluan, A. (2009). Validitas Dan Reliabilitas Suatu Instrumen Penelitian. 6(1), 8797.

Mingkid Gary.J. (2017). EFEKTIVITAS PENGGUNAAN DANA DESA DALAM PENINGKATAN PEMBANGUNAN (Suatu Studi Di Desa Watutumou Dua Kecamatan Kalawat Kabupaten Minahasa Utara). Jurnal Eksekutif, 2(2).

Rahayu, C., \& Festiyed. (2018). Validitas Perangkat Pembelajaran Fisika Sma Berbasis Model Pembelajaran Generatif Dengan Pendekatan Open- Ended Problem Untuk Menstimulus Keterampilan Berpikir. Jurnal Pendidikan Fisika, 7(1), 1-6.

Saputro, B. C. (2018). Meningkatkan Hasil Belajar Sifat-Sifat Cahaya Dengan Metode Inkuiri Pada Kelas V Semester II SD Negeri Sumogawe 04. Jurnal Mitra Pendidikan, 1(9).

Septikasari, R., \& Frasandy, R. N. (2018). Keterampilan 4C Abad 21 Dalam Pembelajaran Pendidikan Dasar. Tarbiyah Al-Awlad, VIII(2), 112-122.

Slameto. (2015). PEMBELAJARAN BERBASIS RISET MEWUJUDKAN PEMBELAJARAN YANG INSPIRATIF Slameto. Satya Widya, 31(2), 102-113.

Sugiyarti, L., Arif, A., \& Jakarta, U. N. (2018). Pembelajaran Abad 21 Di Sd. Prosiding Seminar Dan Diskusi Nasional Pendidikan Dasar, 439-444.

Sulistiawan, A., Yuliasesti, E., Sari, D., \& Situmorang, N. Z. (2020). Validity And Reliability Of Organizational Commitment Using Confirmatory Factor Analysis ( CFA ) Validitas Dan Reliabilitas 
4482 Pengembangan Modul IPA Berbasis Model Research Based Learning pada Keterampilan 4C Siswa Sekolah Dasar-Ressy Monica, Zuhar Ricky, Estuhono

DOI: https://doi.org/10.31004/edukatif.v3i6.1470

Komitmen Organisasi Menggunakan Confirmatory Analisis Faktor ( CFA ). 17(2), 134-144.

Undang-Undang Republik Indonesia Nomor 14 Tahun 2005 Tentang Guru Dan Dosen, (2005).

Undang-Undang Republik Indonesia Nomor 20 Tahun 2003 Tentang Sistem Pendidikan Nasional, 4147 (2003).

Usmeldi, U. (2016). Pengembangan Modul Pembelajaran Fisika Berbasis Riset Dengan Pendekatan Scientific Untuk Meningkatkan Literasi Sains Peserta Didik. Jurnal Penelitian \& Pengembangan Pendidikan Fisika, 2(1), 1-8. Https://Doi.Org/10.21009/1.02101

Widiya Mareta, Dkk. (2021). Jurnal Basicedu. 5(5), 3314-3320. 